\title{
МЕТОДИКА ИССЛЕДОВАНИЯ И ОЦЕНКИ КУМУЛЯТИВНОГО ПОТЕНЦИАЛА РАЗВИТИЯ РЕГИОНАЛЬНЫХ ЭКОНОМИК РОССИЙСКОЙ ФЕДЕРАЦИИ
}

\section{METHODOLOGY FOR RESEARCH AND ASSESSMENT OF CUMULATIVE DEVELOPMENT POTENTIAL OF REGIONAL ECONOMIES OF THE RUSSIAN FEDERATION}

\section{Muratova}

A. Demyanenko

Summary. Economic development is a dual process of expanded production, represented by economic growth on the one hand, and qualitative changes on the other. Its key aspects are the diversity and integrity of the elements of the reproduction mechanism, the renewal on an expanded scale of results and factors of production aimed at the accumulation and corresponding increase of the development potential of national and regional economies. From these points of view, the cumulative development potential of regional economies is the integrated commonality of objectively existing production opportunities (employment, fixed assets, entrepreneurial activity, information technology and institutional components, financial, natural resource and energy elements, as well as the entrepreneurial climate and production specialization) for the implementation of the process of extended reproduction on the basis of a systemic approach, timely elimination of existing bottlenecks, and implementation of priorities. The basic economic outcome of the country 's regions is the gross regional product, which identifies important elements of aggregate demand, such as gross fixed capital formation and final consumption (especially of households), as the fundamental basis for the formation and functioning of the development potential itself. Institutional imperatives and corresponding changes in the economy are not only the development of medium, small (including micro) and individual businesses, but also the inviolability of ownership, the functioning of independent (with corresponding independent control functions), the branches of State power - legislative, executive and judicial, as well as the media and the well-being. Dynamics of society and transformation of social and economic systems includes destruction stages (destructions, overcomings former... Up to disaster), cumulation (partial preservation, continuity, translation, accumulation... are all possible mechanisms of cumulation) and design (creation of a new one).

Keywords: research methodology; potential assessment; export; development potential elements; efficiency of functioning.

\author{
Муратова Людмила Ивановна \\ Д.э.н., професссор, ЧОУ ВО «Ессентукский институт \\ управления, бизнеса и права» \\ gbabkov@mail.ru \\ Демьяненко Андрей Евгеньевич \\ К.э.н., дочент, Северо-Кавказский институт \\ (филиал) АНО ВО Московского гуманитарно- \\ экономического университета, г. Минеральные Воды \\ deanev4@gmail.com
}

Аннотация. Экономическое развитие - это дуальный процесс расширенного производства, представленный, с одной стороны, экономическим ростом, с другой — качественными изменениями. Его ключевыми аспектами являются разнообразие и целостность элементов воспроизводственного механизма, возобновление в расширенном масштабе результатов и факторов производства, нацеленных на накопление и соответствующее увеличение потенциала развития национальной и региональных экономик. С этих позиций кумулятивным потенциалом развития региональных экономик является интегрированная общность объективно существующих возможностей производства (численности занятых, основных фондов, предпринимательской активности, информационно-технологической и институциональной составляющих, финансового, природно-ресурсного и энергетического элементов, а также предпринимательского климата и специализации производства), для осуществления процесса расширенного воспроизводства на основе системного подхода, своевременной ликвидации имеющихся узких мест, и реализации приоритетов. Базисным результатом хозяйственной деятельности регионов страны является валовой региональный продукт, в котором выделяются такие важные элементы совокупного спроса, как валовое накопление основного капитала и конечное потребление (прежде всего домашних хозяйств), являющиеся фундаментальной основой формирования и функционирования собственно потенциала развития. Институциональные императивы и соответствующие преобразования В экономике — это не только развитие среднего, малого (включая микро) и индивидуального бизнеса, но и незыблемость права собственности, функционирования независимых друг от друга (с соответствующими независимыми контрольными функциями), ветвей государственной власти законодательной, исполнительной и судебной, а также средств массовой информации и благосферы. Динамика социума и преобразования социально-экономических систем включает этапы деструкции (разрушения, преодоления прежнего... вплоть до катастрофы), кумуляцию (частичное сохранение, преемственность, трансляцию, накопление... - все это возможные механизмы кумуляции) и конструкцию (созидание нового).

Ключевые слова: методика исследования; оценка потенциала; экспорт; элементы потенциала развития; эффективность функционирования. 
$\mathbf{M}$ етодика исследования и оценки потенциала развития национальной экономики Российской Федерации за 2000-20017 гг. включает в себя семь этапов.

На первом этапе осуществляется информационное обеспечение исследования, исходя из данных Росстата, как по структурным элементам собственно потенциала экономического развития, так и по результативным признакам, прежде всего, характеристикам валового внутреннего продукта.

В рамках алгоритма анализа детерминированных зависимостей на втором этапе осуществляется индексный анализ стоимостных показателей с выделением факторов физических объемов и цен, на третьем проводится оценка стоимостных характеристик в постоянных ценах (то есть в сопоставимом виде), на четвертом выявляются закономерности трансформаций элементов потенциала с их экстраполяцией на ближайший период.

Измерение потенциала экономического развития, с учетом его использования в экономических расчетах, осуществляется в рамках пятого - седьмого этапов исследования, исходя из многофакторного корреляционно-регрессионного моделирования валового внутреннего продукта (с отбором наиболее существенных факторов и наилучшей модели), позволяющего в итоге измерить эффективность функционирования национальной экономики в динамике.

Значимыми движителями экономического развития, существенными элементами потенциала, являются расходы на экономику национального и регионального бюджетов, денежные вклады юридических и физических лиц в банковской системе, сальдированный финансовый результат субъектов хозяйствования, и что не менее важно, объем потребительских расходов населения, которые активируют своей покупательной способностью отрасли экономики, виды экономической деятельности.

Необходимо отметить, что при изучении динамических рядов возможно и необходимо исследование закономерностей развития. Дело в том, что изменения, наблюдающиеся во временных процессах, констатируются при краткосрочном периоде (по нескольким наблюдениям) тем или иным трендом, тогда как в рамках относительно долгосрочного периода может быть выявлено наличие или отсутствие закономерностей развития, как устойчивых, количественно доказанных и математически формализованных трансформаций и зависимостей социально-экономических характеристик.

В отличие от закона закономерность проявляется не всегда, а в большинстве случаев с определенной ве- роятностью функционирования выявленной тенденции, связи. В экономике функционируют статистические закономерности, характеризующие форму проявления повторяемости, последовательности, порядка изменений в массовых явлениях. Это причинно-следственные связи, проявляющиеся в последовательности повторяемости и регулярности массовых явлений общественной жизни, относящихся к определенному пространству и времени [5, с. 84].

Анализ показывает, что изменения социально-экономических характеристик развития Российской Федерации в 2000-2017 гг. во многом имеют характер специфических закономерностей с очевидной пролонгацией их на ближайшую перспективу [11, с. 258]. Именно большая зависимость от экспорта природных ресурсов, непосредственно влияющего на специфику развития, является характерной чертой российской экономики, о чем наглядно свидетельствуют данные таблицы 1.

В целом за анализируемые 18 лет (2000-2017 гг.) общий экспорт российских товаров увеличился (на фоне 69657 млн. долларов в 1999 г.) с 99220 млн. долларов в 2000 г. до 353547 млн. долларов в 2017 г. то есть В 3,56 раз. Анализ экспорта по годам динамики позволяет сделать ряд важных выводов. Во-первых, наблюдается тенденция непрерывного роста в первом девятилетии вплоть до 2008 г. (466298 млн. долларов). Во-вторых, в 2009 г. и, соответственно, в 2010 г. объемы экспорта, по сравнению с 2008г, снижаются (до 297155 и 392674 млн. долларов). В-третьих, максимальные значения общего экспорта наблюдаются в 2011-2013 гг. (ежегодно свыше 500 млрд. долларов). В-четвертых, далее (в 2014-2017 гг.) на фоне волнообразной тенденции наблюдается снижение экспорта с минимумом в 2016 г. (281709 млн. долларов). В итоге, среднегодовые характеристики общего экспорта в 2000-2008 гг. составили 217233 млн. долларов, в 2009-2013 гг. 450901 млн. долларов, в 2014-2017 гг. 368370 млн. долларов.

Аналогичные процессы наблюдаются также по экспорту минеральных продуктов, то есть природных ресурсов (нефти и нефтепродуктов, газа, электроэнергии, фосфатов кальция, цемента, асбеста, руды и концентратов железных, угля каменного, лигнина, кокса) и главных из них - нефти, нефтепродуктов и газа.

Соответствующие среднегодовые характеристики по ним составляют: в 2000-2008 гг. 217233 млн. долларов по минеральным продуктам, в том числе, 133589 по нефти, нефтепродуктам и газу; в 2009-2013 гг. 450901 и 296042; в 2014-2017 гг. 368370 и 217223 млн. долларов.

Начало снижения экспортных нефтегазовых цен, являющихся базисом функционирования экономики 
Таблица 1. Экспорт природных ресурсов и развитие российской экономики

\begin{tabular}{|c|c|c|c|c|c|c|c|}
\hline \multirow{2}{*}{$\begin{array}{l}\text { Годы и пери- } \\
\text { оды }\end{array}$} & \multicolumn{2}{|c|}{$\begin{array}{l}\text { Экспорт минеральных продуктов, } \\
\text { млн. долларов }\end{array}$} & \multicolumn{2}{|c|}{$\begin{array}{l}\text { Средние цены, дол- } \\
\text { ларов }\end{array}$} & \multicolumn{3}{|c|}{ Индексы физических объемов,\% } \\
\hline & всего & $\begin{array}{l}\text { в т.ч. нефти, нефтепро- } \\
\text { дуктов } \\
\text { и газа }\end{array}$ & $\begin{array}{l}\text { за } 1 \text { т. } \\
\text { нефти }\end{array}$ & $\begin{array}{l}\text { за тыс. м3 } \\
\text { газа }\end{array}$ & ВВП & инвестиций & $\begin{array}{l}\text { доходов насе- } \\
\text { ления }\end{array}$ \\
\hline 1999 & 32689 & 24683 & 105,0 & 55,3 & 106,4 & 105,3 & 87,7 \\
\hline 2000 & 55488 & 52866 & 175,0 & 85,9 & 110,0 & 117,4 & 112,0 \\
\hline 2001 & 54653 & 52281 & 151,0 & 101 & 105,1 & 111,7 & 108,7 \\
\hline 2002 & 58897 & 57074 & 154,0 & 85,7 & 104,7 & 102,9 & 111,3 \\
\hline 2003 & 76593 & 72861 & 174,0 & 106 & 107,3 & 112,7 & 115,0 \\
\hline 2004 & 104950 & 99444 & 226,0 & 109 & 107,2 & 116,8 & 110,5 \\
\hline 2005 & 156372 & 148620 & 330,0 & 151 & 106,4 & 110,2 & 112,4 \\
\hline 2006 & 198631 & 190466 & 412,0 & 216 & 108,2 & 117,8 & 113,5 \\
\hline 2007 & 228436 & 218568 & 470,0 & 234 & 108,5 & 123,8 & 112,1 \\
\hline 2008 & 326314 & 310124 & 663,0 & 354 & 105,2 & 109,5 & 102,4 \\
\hline 2009 & 203408 & 190708 & 407,0 & 249 & 92,2 & 86,5 & 103,2 \\
\hline 2010 & 271888 & 252421 & 546,0 & 273 & 104,5 & 106,3 & 105,9 \\
\hline 2011 & 367635 & 341700 & 744,0 & 343 & 104,3 & 110,8 & 100,5 \\
\hline 2012 & 373998 & 346322 & 754,0 & 346 & \begin{tabular}{|l}
103,7 \\
\end{tabular} & 106,8 & 104,6 \\
\hline 2013 & 375815 & 349059 & 734,0 & 336 & 101,8 & 100,8 & 104,0 \\
\hline 2014 & 350266 & 324390 & 689,0 & 314 & \begin{tabular}{|l}
100,7 \\
\end{tabular} & 98,5 & 99,3 \\
\hline 2015 & 219167 & 203148 & 366,0 & 225 & 97,5 & 89,9 & 96,8 \\
\hline 2016 & 169145 & 151183 & 289,0 & 157 & 103,5 & 99,8 & 94,2 \\
\hline 2017 & 216184 & 190172 & 369,0 & 179 & 101,5 & 104,4 & 98,8 \\
\hline 2000-2008 & 217233 & 133589 & 306 & 160 & 107,0 & 117,7 & 110,9 \\
\hline 2009-2013 & 450901 & 296042 & 637 & 309 & 101,3 & 106,9 & 103,6 \\
\hline 2014-2017 & 368370 & 217223 & 428 & 219 & 100,8 & 106,5 & 97,3 \\
\hline
\end{tabular}

Авторские расчеты по данным Росстата $[6 ; 7 ; 9]$

России, явилось с 2014 г. триггером современного этапа развития страны со стагнацией материального производства, деиндустриализацией, низкими доходами населения и объемами инвестиционного капитала, неразвитостью потребительского рынка, огромными диспропорциями и ухудшением состояния большинства регионов, сигнализирующих о гипертрофированности производства, распределения, потребления и накопления, чем обусловливается необходимость последующих структурных трансформаций, восстановления и повышения потенциала развития национальной и региональных экономик.

Кумуляция в экономике - это скопление, накопление, концентрация, суммирование, увеличение, усиление. В соответствии с этим, кумулятивным эффектом является концентрация, результативность действий осуществляемых в определенном четко выраженном направлении. Выделяются различные виды кумуляции: материальная, как суммирование (с позиций анализиру- емой проблемы) потенциала экономического развития при его систематическом пополнении и функциональная, как суммирование эффекта деятельности отдельных элементов потенциала развития [2, с. 111].

Именно накопление во времени и суммирование в пространстве элементов воспроизводственного процесса свидетельствуют о кумулятивном характере потенциала развития региональных экономик, который представляет собой интегрированную совокупность живого и прошлого труда, структурного и коммуникационно-технологического факторов и институциональных преобразований в процессе функционирования социально-экономических систем, в том числе, субъектов Российской Федерации [1, с. 75].

Деструкция как социума, так и социально-экономических систем может быть как внезапной, так и медленно развивающейся, в социуме [4, с. 126] вследствие экологических факторов (радиационного, промышленного 
Формирование базы данных оценки потенциала развития региональных экономик

Обоснование базисных характеристик потенциала развития региональных экономик

Система ключевых показателей потенциала развития региональных экономик

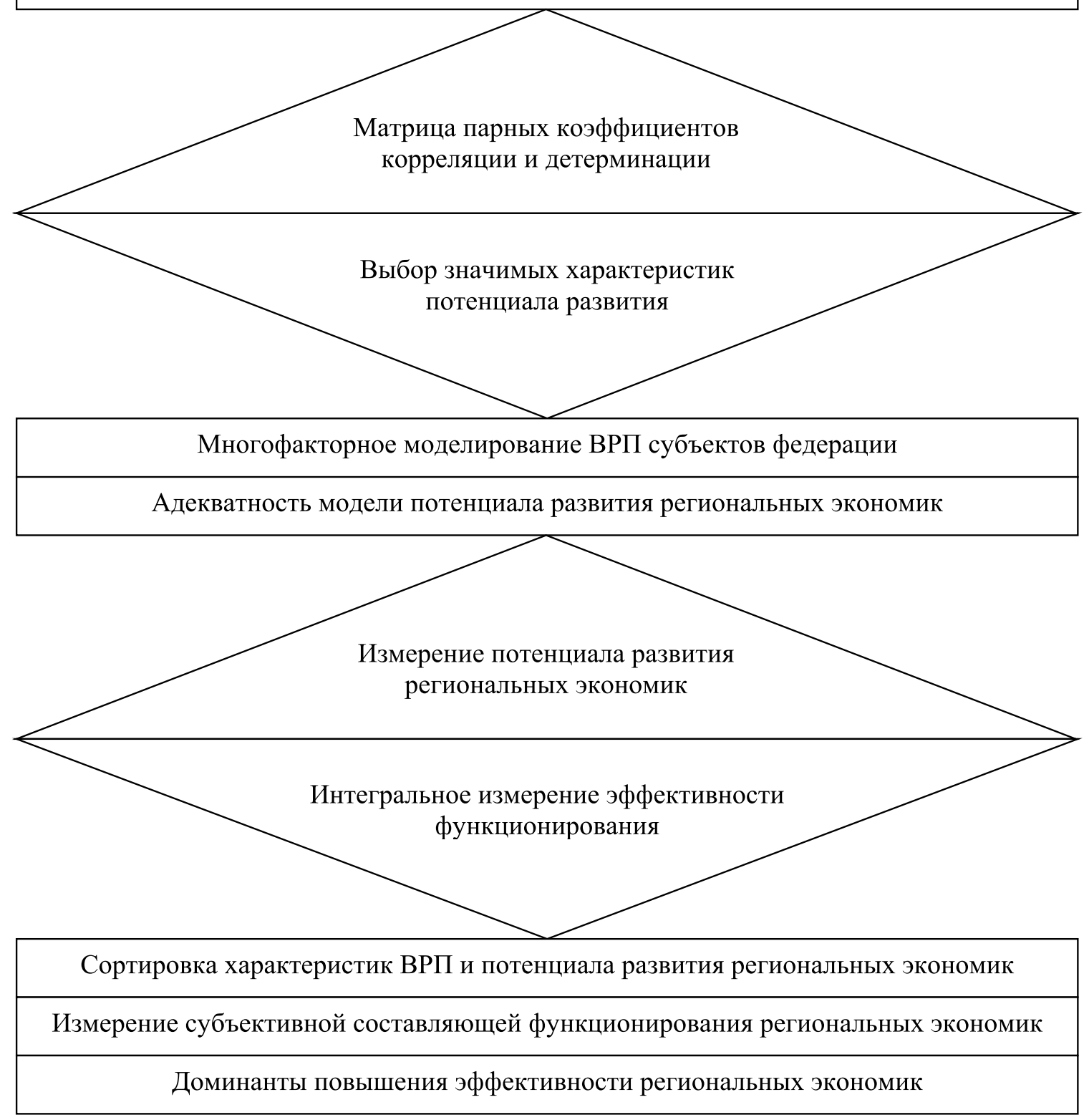

Рис. 1. Методика познания и измерения потенциала развития региональных экономик

и потребительского загрязнения окружающей среды), хронического действия лекарств и ядов (в том числе ныне технического пальмового масла) формирования зон повышенной конфликтности, накопления токсикантов в организме и стрессового эффекта, с учетом необратимости временных изменений, когда в рамках кумуляции последствий каждое последующее состояние возникает на основе суммирования предыдущих.
Проблема здесь в том, что если чуть-чуть негативно изменился один, второй, третий ... и последующие факторы, то кумуляция этих изменений обуславливает существенные трансформации как социума, так и социально-экономических систем. С позиций рыночной модели функционирования экономики активными элементами кумуляции или деструкции являются внушение, подражание и другие процессы, регулирующие передачу 
Таблица 2. Группировка регионов Российской Федерации по ВРП, 2017 г.

\begin{tabular}{|l|l|l|l|l|l|l|l|l|}
\hline $\begin{array}{l}\text { Группы реги- } \\
\text { онов по ВРП }\end{array}$ & $\begin{array}{l}\text { ВРП, млрд. } \\
\text { руб. }\end{array}$ & $\begin{array}{l}\text { Основные } \\
\text { фонды, } \\
\text { млрд. руб. }\end{array}$ & $\begin{array}{l}\text { Финансо- } \\
\text { вые ресур- } \\
\text { сы, млрд. } \\
\text { руб. }\end{array}$ & $\begin{array}{l}\text { Малые } \\
\text { прдприя- } \\
\text { тия, млрд. } \\
\text { руб. }\end{array}$ & $\begin{array}{l}\text { Условное } \\
\text { топливо, } \\
\text { тыс. т }\end{array}$ & $\begin{array}{l}\text { Специали- } \\
\text { зация,\% }\end{array}$ & $\begin{array}{l}\text { Налоги } \\
\text { в боджет } \\
\text { региона, } \\
\text { млрд. руб. }\end{array}$ & $\begin{array}{l}\text { Экспорт } \\
\text { природных } \\
\text { ресурсов, } \\
\text { млн. дол. }\end{array}$ \\
\hline 1 группа & 84 & 219 & 117 & 40 & 1318 & 88,5 & 8,8 & 22 \\
\hline 2 группа & 196 & 533 & 237 & 125 & 3490 & 85,2 & 20,7 & 312 \\
\hline 3 группа & 303 & 972 & 398 & 188 & 5331 & 91,5 & 35,4 & 255 \\
\hline 4 группа & 436 & 1206 & 564 & 275 & 8839 & 95,5 & 47,3 & 1143 \\
\hline 5 группа & 627 & 1768 & 723 & 344 & 8688 & 109,3 & 72,7 & 1420 \\
\hline 6 группа & 999 & 2505 & 1109 & 614 & 17389 & 104,4 & 108,5 & 3572 \\
\hline 7 группа & 3321 & 8325 & 3517 & 2263 & 30887 & 123,6 & 358,5 & 15708 \\
\hline
\end{tabular}

Авторские расчеты по данным Росстата $[6 ; 7 ; 10]$

информации и соответствующие социально-экономические изменения [3, с. 186].

С учетом формирования, на основе постоянной кумуляции, потенциала экономического развития, на рис. 1. рассматриваются аспекты сущности фаз познания, а также компонентов оценки и использования потенциала развития региональных экономик.

В рамках первой фазы познания осуществляется информационное обеспечение исследования, с позиций компонентов формирования исходной базы показателей по субъектам Российской Федерации для оценки их потенциалов развития, обоснования базисных характеристик потенциала с выделением их системы (из десяти ключевых показателей), формирования и функционирования потенциала развития региональных экономик, нацеленного на максимизацию валовых региональных продуктов, обеспечение возрастающих потребностей населения.

Сущность второй фазы исследования определяется социально-экономическим анализом субъектов Российской Федерации (как в статике за 2017 г., так и в динамике за 2000-2017 г.г.) на основе системы методов и приемов экономического познания, позволяющих в итоге на основе расчета матрицы взаимосвязанных парных коэффициентов корреляции и детерминации осуществить выбор наиболее значимых характеристик потенциала развития региональных экономик.

Исходя из этого, в рамках третьей фазы исследования осуществляется многофакторное регрессионное моделирование валового регионального продукта субъектов Российской Федерации (с перебором как самих моделей, так и входящих в них факторов), оценкой адекватности модели и расчетом ошибки аппроксимации с позиций соответствия полученной модели реальной действительности.
Сущность четвертой фазы исследования заключается, с одной стороны, в измерении собственно потенциала развития региональных экономик субъектов Российской Федерации (с анализом структуры потенциала), с другой стороны, в оценке эффективности функционирования региональных экономик страны, с учетом не только частных характеристик, но также интегрального подхода. В итоге, в рамках пятой фазы исследования осуществляется использование характеристик потенциала развития региональных экономик на основе компонентов, во-первых, сортировки характеристик валового регионального продукта и потенциала развития, во-вторых, измерения субъективной составляющей хозяйственной деятельности, в-третьих, выявления резервов роста и доминантов повышения эффективности функционирования региональных экономик субъектов Российской Федерации.

С позиций объемов валового регионального продукта в 2017 г. в Российской Федерации выделяется семь групп регионов: очень мелких, мелких, меньше среднего уровня, среднего уровня, выше среднего уровня, крупных и очень крупных (табл. 2).

В группу очень мелких (по объемам ВРП регионов страны в ранжированном ряду (от 44572 до 151607 млн. руб.), входят Республика Алтай, Еврейская автономная область, Республика Ингушетия, Республика Тыва, Республика Калмыкия, Чукотский автономный округ, г. Севастополь, Карачаево-Черкесская Республика, Республика Адыгея, Республика Северная Осетия - Алания, Кабардино-Балкарская Республика и Псковская область.

В группу самых крупных регионов Российской Федерации по объемам валового регионального продукта в ранжированном ряду (от 1347143 до 15724910 млн. руб.), входят Ростовская область, Челябинская область, Самарская область, Республика Башкортостан, Красноярский край, Республика Татарстан, Свердловская 
Таблица 3. Основные элементы потенциала развития по полярным регионам федеральных округов РФ, 2017 г.

\begin{tabular}{|c|c|c|c|c|c|c|c|c|c|c|c|}
\hline$\frac{\sigma}{\frac{0}{6}}$ & 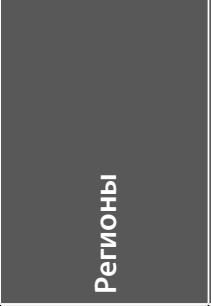 & 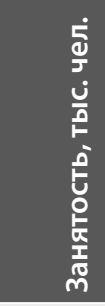 & 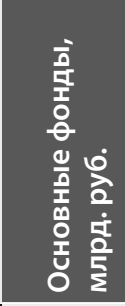 & 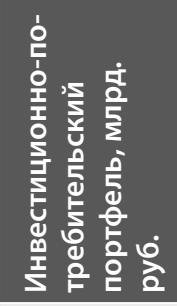 & 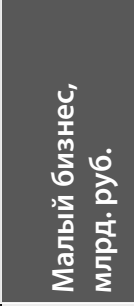 & 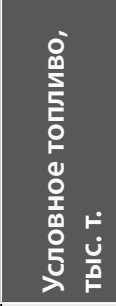 & 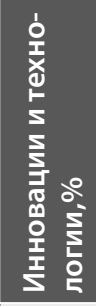 & 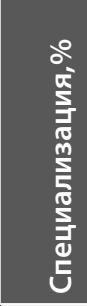 & 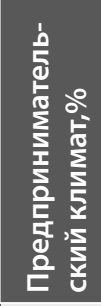 & 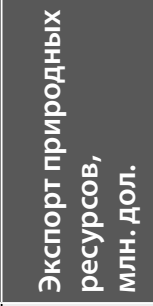 & 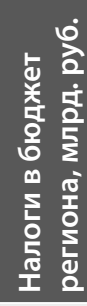 \\
\hline \multirow[t]{2}{*}{ ЦФО } & $\begin{array}{l}\text { Костромская } \\
\text { область }\end{array}$ & 290,8 & 437 & 195 & 142 & 2823 & 18 & 82,6 & 97 & 205,6 & 17,8 \\
\hline & г. Москва & 8730 & 36605 & 16235 & 14292 & 47994 & 3055 & 93,4 & 127 & 128770 & 1796 \\
\hline \multirow{2}{*}{ С ЗФО } & $\begin{array}{l}\text { Псковская } \\
\text { область }\end{array}$ & 280,3 & 387 & 226 & 142 & 2089 & 9 & 79,7 & 120 & 155,4 & 15,3 \\
\hline & \begin{tabular}{|l|} 
г.Санкт- \\
Петербург \\
\end{tabular} & 3187 & 7164 & 4409 & 3924 & 28139 & 467 & 84,8 & 191 & 16258 & 453 \\
\hline \multirow{2}{*}{ ЮФО } & $\begin{array}{l}\text { Республика } \\
\text { Калмыкия } \\
\end{array}$ & 111,1 & 204 & 48 & 12 & 615 & 1 & 119,1 & 79 & 0,0 & 5,5 \\
\hline & $\begin{array}{l}\text { Краснодар- } \\
\text { ский край }\end{array}$ & 2599 & 5938 & 3072 & 1790 & 20251 & 208 & 79,7 & 111 & 4782 & 217 \\
\hline \multirow{2}{*}{ СКФО } & \begin{tabular}{|l} 
Республика \\
Ингушетия \\
\end{tabular} & 179,4 & 119 & 62 & 13 & 693 & 1 & 77,6 & 97 & 0,6 & 3,5 \\
\hline & $\begin{array}{l}\text { Ставрополь- } \\
\text { ский край }\end{array}$ & 1234 & 1777 & 1058 & 596 & 8941 & 40 & 79,0 & 95 & 544,8 & 64.9 \\
\hline \multirow{2}{*}{ ПрФО } & $\begin{array}{l}\text { Республика } \\
\text { Марий-Эл }\end{array}$ & 291,7 & 418 & 178 & 168 & 2572 & 16 & 101,2 & 91 & 286,4 & 17,2 \\
\hline & \begin{tabular}{|l} 
Республика \\
Татарстан \\
\end{tabular} & 1945 & 4659 & 2450 & 965 & 24223 & 411 & 105,8 & 99 & 12040 & 228 \\
\hline \multirow[b]{2}{*}{ УФО } & $\begin{array}{l}\text { Курганская } \\
\text { область }\end{array}$ & 338,6 & 726 & 207 & 83 & 3477 & 10 & 81,8 & 75 & 46,2 & 19,3 \\
\hline & $\begin{array}{l}\text { Ханты- } \\
\text { Мансийский } \\
\text { АО }\end{array}$ & 1078 & 12543 & 2257 & 423 & 61168 & 111 & 264,1 & 89 & 14372 & 229 \\
\hline \multirow{2}{*}{ СФО } & $\begin{array}{l}\text { Республика } \\
\text { Алтай }\end{array}$ & 83,4 & 132 & 74 & 28 & 558 & 2 & 77,5 & 100 & 17,6 & 4,2 \\
\hline & $\begin{array}{l}\text { Красноярский } \\
\text { край }\end{array}$ & 1411 & 3605 & 1837 & 710 & 27044 & 163 & 130,3 & 112 & 5147 & 204 \\
\hline \multirow[b]{2}{*}{ ДФО } & Еврейская АО & 67,2 & 252 & 53 & 17 & 807 & 1 & 74,1 & 88 & 13,3 & 6,1 \\
\hline & $\begin{array}{l}\text { Республика } \\
\text { Саха (Якутия) }\end{array}$ & 492,1 & 2208 & 939 & 158 & 7063 & 41 & 143,7 & 83 & 872,3 & 102 \\
\hline
\end{tabular}

Авторские расчеты по данным Росстата $[6 ; 7 ; 8 ; 10]$

область, Краснодарский край, Ямало-Ненецкий автономный округ, Ханты-Мансийский автономный округ, Московская область, г. Санкт-Петербург и г. Москва.

С позиций федеральных округов Российской Федерации, в каждом из них выделяются полярные регионы с соответствующими характеристиками, которые свидетельствуют об огромных различиях субъектов федерации как внутри округов, так и между ними (табл. 3).

Расчеты показывают, что г. Москва по большинству элементов потенциала развития (численности занятого населения; основным фондам; финансовой обеспеченности, как с позиций потребительско-инвестиционного портфеля, так и налогов, поступающих в региональный бюджет; малого бизнеса; экспорта природных ресурсов; инноваций и информационно-коммуникационных технологий) кратно превышает характеристики других регионов.

Вместе с тем, с позиций предпринимательского климата, более высокий уровень наблюдается по г. Санкт-Петербургу, с позиций использования условного топлива - по Ханты-Мансийскому автономному 
округу, по специализации производства - по Республике Калмыкия (в связи с тем, что здесь материальное производство, по существу представлено только отраслью сельского хозяйства, охоты, рыболовства и рыбоводства).

Анализируя различия полярных регионов по федеральным округам, следует отметить, что везде и практически по всем элементам потенциала развития большие лучшие характеристики наблюдаются по очень крупным и крупным регионам, являющимися административными центрами того или иного федерального округа. Отметим отдельно характеристики, определяющие финансовую обеспеченность регионов во взаимосвязи с экспортом природных ресурсов. Наряду с Москвой, в каждом округе объем инвестиционно-потребительского портфеля (включающего, с одной стороны, потребительский рынок, с другой стороны, инвестиционный капитал) многократно выше в административных центрах.

Специфические различия наблюдаются по экспорту минеральных продуктов (нефти, газа и др.), где, наряду с большими характеристиками наблюдающимися в ресурсодобывающих регионах (Ханты-Мансийский автономный округ, Республика Татарстан, Красноярский и Краснодарский края), лучшие параметры наблюдаются по г. Москве и г. Санкт-Петербургу, в связи с юрисдикцией многих ресурсодобывающих компаний в этих финансовых центрах. Соответствуют этому также налоги и платежи, поступающие в бюджет каждого из анализируемых регионов (за исключением поступлений, идущих в федеральную казну). В г. Москва поступления в свой бюджет в 2017 г. составили 1796 млрд. руб. при 204-229 млрд. руб. по Красноярскому и Краснодарскому краям, Республике Татарстан и Ханты-Мансийскому автономному округу, на фоне минимальных характеристик по Еврейской автономной области (6,1 млрд. руб.), Республике Калмыкия (5,5 млрд. руб.), Республике Алтай (4,2 млрд. руб.) и Республике Ингушетия, где поступления в свой бюджет за анализируемый период составили 3,5 млрд. руб.

Если по большинству административных центров федеральных округов наблюдается финансовая самообеспеченность, по другим имеются возможности для ее достижения или повышения, то мелкие регионы такой возможности де-факто не имеют (так по Еврейской автономной области доля безвозмездных поступлений в региональном бюджете составляет 32,1\%, по Республике Калмыкия 45,9\%, по Республике Алтай 69,2\%, а по Республике Ингушетия 81,3\%).

Важным фактором потенциала развития региональных экономик является предпринимательская активность, в том числе, с позиций малого предприниматель- ства (включая микро-уровень), о чем свидетельствуют данные таблицы 3.

Полученные данные позволяют выявить три наблюдающихся специфических особенности. Во-первых, производительность живого труда в крупных регионах, административных центрах федеральных округов повсеместно кратно выше, по сравнению с мелкими регионами. Во-вторых, производительность труда в малом бизнесе в крупных регионах (за исключением Приволжского федерального округа) выше по сравнению с мелкими регионами. В-третьих, за исключением Ханты-Мансийского федерального округа, производительность живого труда в малых предприятиях (включая микро-предприятия) значительно больше, зачастую в разы, как к регионам в целом, так и к организациям регионов: от 1,22-1,71 раз по Республике Татарстан, г. Санкт-Петербургу и г. Москва до 7,23-9,55 раз по Республикам Алтай, Саха (Якутия) и Калмыкия. По Республике Ингушетия данный показатель составляет 61,6 раз, что по видимому объясняется качеством учета как оборота организаций, так и функционирования малого бизнеса.

Во многом функционирование малого предпринимательства в регионах страны обусловлено особенностями предпринимательского климата, который как в стране в целом, так и по регионам вызывает большие нарекания. Именно его низким и ухудшающимся уровнем обусловлен тот факт, что численность предприятий малого бизнеса (включая микро-уровень) в последние годы сокращается, например, в 2018 г., по сравнению с 2017 г., уменьшилась на 94634 единиц [6].

Зачастую для интегральной оценки эффективности функционирования региональных экономик используется подход, основанный на применении средней арифметической простой, когда сумма частных характеристик делится на их количество. Однако, очевидно, что значимость отдельных показателей, по влиянию на результативность экономической деятельности, во-первых, различна, а, во-вторых, применяемые, как правило, суммирование различных абсолютных и относительных характеристик приводит к экономическому абсурду. Очевидно, что итоговая, интегральная оценка эффективности функционирования региональных экономик должна осуществляться исходя из принципа адекватного соотношения результатов производства с совокупностью факторов воспроизводственного процесса, в качестве которой и выступает кумулятивный потенциал развития.

Анализ итоговой кумулятивной эффективности функционирования анализируемых регионов позволяет сделать ряд выводов. Во-первых, повсеместно, то есть по каждому федеральному округу характеристики эф- 
фективности существенно выше в крупных (по масштабам деятельности) регионах, во-вторых, самые высокие оценки наблюдаются по Красноярскому краю и Хан-
ты-Мансийскому автономному округу (Югра), при самых низких по Республике Калмыкия и Еврейской автономной области, с разницей до 3 раз.

\section{ЛИТЕРАТУРА}

1. Алексеев А.В., Кузнецова И. В. Сравнительная характеристика методик оценки уровня социально-экономического развития региональной социально-экономической системы // Новые технологии. - 2018. - № 2. С. 73-79.

2. Бабков Г.А., Демьяненко А. Е. Специфика и доминанты реализации потенциала развития региональных экономик ЦФ0 // Вестник Белгородского университета кооперации, экономики и права. Фундаментальные и прикладные исследования. Международный научно-теоретический журнал.— № 6 (79). 2019. - C. 108-119.

3. Конюхов Н. И. Психоэкономика: глобализация, рынки, кризис.- М.: Литагент.-2012. -420 c.

4. Левада Ю.А. и др. Время перемен. Предмет и позиция исследователя.—- М.: Новое литературное обозрение.— 2016. — 872 с.

5. Муратова Л.И., Таран 0.Л. Отраслевая ассиметрия, диагностика и использование ресурсного потенциала в региональной экономике. Кисловодск: Тьютер. - 2008. - $140 \mathrm{c}$.

6. Национальные счета России в 2014-2018 годах: Стат. сб./ Росстат.- М., - 2019. - 263 с.

7. Регионы России. Социально-экономические показатели. - М.: Росстат.-2018. - 1164 c.

8. Рейтинг инвестиционной привлекательности регионов России. - M.: raex-a.ru [электронный ресурс]. URL: https://delen.ru/investicii/rejting-regionov-poinvesticionnoj-privlekatelnosti.html (дата обращения 23 января 2020 г.).

9. Российский статистический ежегодник. - М.: Росстат. - 2018. - 696 с.

10. Финансы России.— М.: Росстат.-2018. - 439 с

11. Demyanenko A. E. Formation and use of the development capacity of regional economies Central Federal // Humanities \& Social Sciences Reviews elSSN: 23956518 , Vol 7, No 6, 2019, P. 255-262.

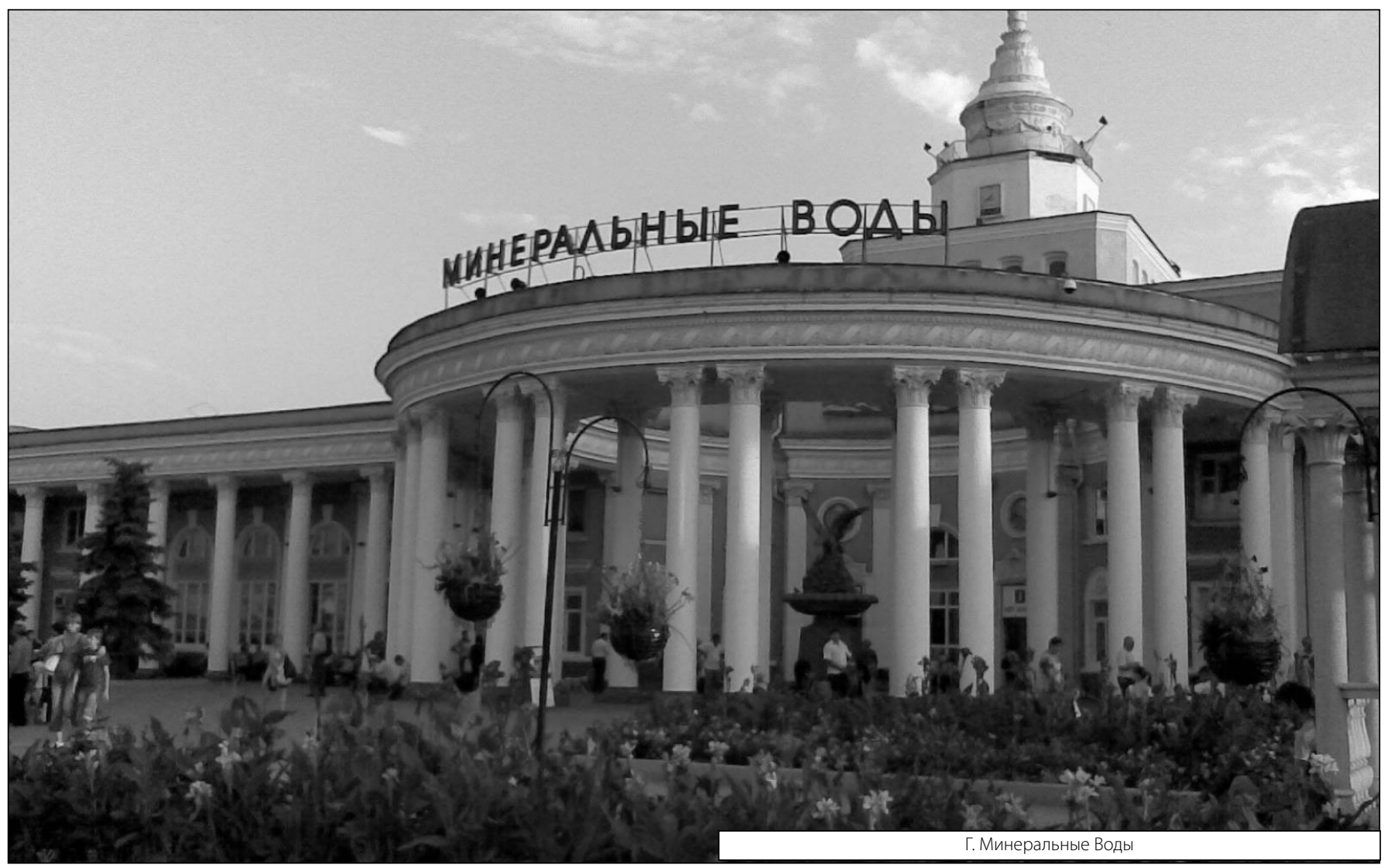

